\title{
Information Technology/Systems Adoption in the Public Sector:
}

\section{Evidence From the Illinois Department of Transportation}

\author{
Roya Gholami, NEOMA Business School, France \\ Neetu Singh, University of Illinois, Springfield, USA \\ Pranav Agrawal, University of Illinois, Springfield, USA \\ Karina Espinosa, University of Illinois, Springfield, USA \\ Dalal Bamufleh, University of Illinois, Springfield, USA
}

\begin{abstract}
State government has been moving from manual and paper-based processes to digital services. However, digital divide, declining trust in technology, and low IT/IS adoption rates by public sector employees are important challenges for successful delivery of e-government services to citizens. Previous studies in the area of IT/IS adoption and e-government have mainly focused on citizens. This paper examines IT/IS adoption by employees rather than citizens and the focus is on non-market environment and state government agencies. A research model has been proposed based on the theory of planned behavior (TPB) and technology acceptance model (TAM) which has been extended to include digital divide related constructs and trust in technology. To test the proposed model, a survey was conducted among early adopters of Office 365 at Illinois Department of Transportation (IDOT) in Springfield and Chicago. The paper contributes to research on IT/IS adoption in public sector. The findings also provide insightful design and practical implications for successful IT/IS deployment in public sector.
\end{abstract}

\section{KEYWORDS}

Digital Divide, E-Government, IT/IS Adoption, Public Sector, Trust

\section{INTRODUCTION}

Information technology/systems (IT/IS) adoption by public sector employees is an essential first step for successful implementation of e-government, and delivery of services to citizens. Al Gore, the US Vice President in 1993 urged government state agencies to use IT/IS to transform citizens' interaction with government (Gore, 1997). IT/IS adoption allows state government agencies to provide quality public services and better respond to constituents' needs, improve performance, and effectively use resources and taxpayer money (Robinson, 1998; Vanagunas, 1999; Bharadwaj, 2000; Afuah, 2002). Organizational resources can be tangible such as IT/IS or intangible such as human skills (Choi, 2014). Previous studies suggest IT/IS adoption is a tangible asset that contributes to organizational 
capabilities in terms of 'socialization capabilities' and 'coordination capabilities' (Roberts et al., 2012; Liu et al., 2018).

However, the adoption of IT/IS by state government employees has been a challenge. Staff need to have the resources to learn how to use IT/IS and to understand its capabilities. Lack of access to technology can be referred to as 'digital divide', more specifically access divide (Belanger and Carter, 2009; van Dijk and Hacker 2003) (Bélanger \& Carter, 2009; Van Dijk \& Hacker, 2003) (Bélanger \& Carter, 2009; Van Dijk \& Hacker, 2003) (Bélanger \& Carter, 2009; Van Dijk \& Hacker, 2003) (Bélanger \& Carter, 2009; Van Dijk \& Hacker, 2003) (Bélanger \& Carter, 2009; Van Dijk \& Hacker, 2003) (Bélanger \& Carter, 2009; Van Dijk \& Hacker, 2003) (Bélanger \& Carter, 2009; Van Dijk \& Hacker, 2003) (Bélanger \& Carter, 2009; Van Dijk \& Hacker, 2003) (Bélanger \& Carter, 2009; Van Dijk \& Hacker, 2003). According to Pick and Sarkar (2016), the term 'digital divide' was born in mid-90's and it was focused on technology access. The reason why the definition revolves around technology access was the technology cost. However, the dropping cost of technology as well as the impact of many social initiatives to improve technology access to the community has updated the digital divide definition. Now, the term incorporates technological literacy besides access, and digital divide has extended to 'skills divide' (Ferro et al., 2011; Pick and Nishida, 2015).

Skills divide relates to the disparity due to the lack of skills to use IS (Pick and Sarkar, 2016). One of the primary domains where digital divide has played an important role is government. The potential advantages of e-government services do not usually reach all citizens due to the disparity in technology access which may be caused by income, education and skills level disparity (Becker, 2003). Another study was conducted by the Internet and American Life Project under PEW Research Center in 2013 to find how digital divide is related to internet non-usage. The study sample included 2,252 adults who did not use Internet or email, and the data was collected through a survey as well as interviews. The findings showed a few primary factors that were associated with the internet non-usage including attitude, age, skills, usability, ease of use, price, availability, and access (Caumont, 2013). The significant portion of the identified factors belong to either 'digital access divide' or 'digital skills divide'. Figure 1 shows the inequality of IT usage among rural, urban and suburban US adults based on a survey conducted by PEW Research Center in 2019 - (Perrin, 2019).

Basware (2015) argues digital transformation in government agencies through adoption of IT/IS, saves costs, accelerates the processing time and enhances the state financial performance. Graham (2015) suggests governments would save more than 85 percent of their processing costs with e-government. A study on 344 counties in US was carried out to investigate the relationship between the type and level of e-government services provided in each county and the county poverty level (Baired et al., 2012). The findings indicated 75 percent of the evaluated counties have some internet/ web presence regardless of the county poverty level.

However, not all government agencies could reap benefits from e-government due to the low IT/IS adoption (Baird et al., 2012). Only 15 percent of the implemented e-government systems have achieved the expected benefits (Heeks, 2008). The digital divide is considered as one of the challenges faced by state government agencies because it threatens the successful digital transformation (Arkinson and Castro, 2008). Digital divide (Nam, 2014) and low IT/IS adoption (Pontiggia and Virili, 2010) prohibits the government agencies from enhancing information access, improving the citizens-government communication, delivering better services to internal and external stakeholders, decreasing administrative and managerial cost and enhancing business processes efficiency and effectiveness (UNPAN, 2010).

Digital divide can be defined from three perspectives: 1) access divide (the disparity between the haves and the have nots), 2) multi-dimensional divide (the divide that is spanned across the parameters such as social, political, educational, and economic), and 3) multi-perspective divide (digital divide based on the intersections of users' race, gender, class, and worldview that further conceptualize the digital divide) (Helbig, Gil-García, \& Ferro, 2009; Van Dijk \& Hacker, 2003) Carter and Weerakkody, 2008). 


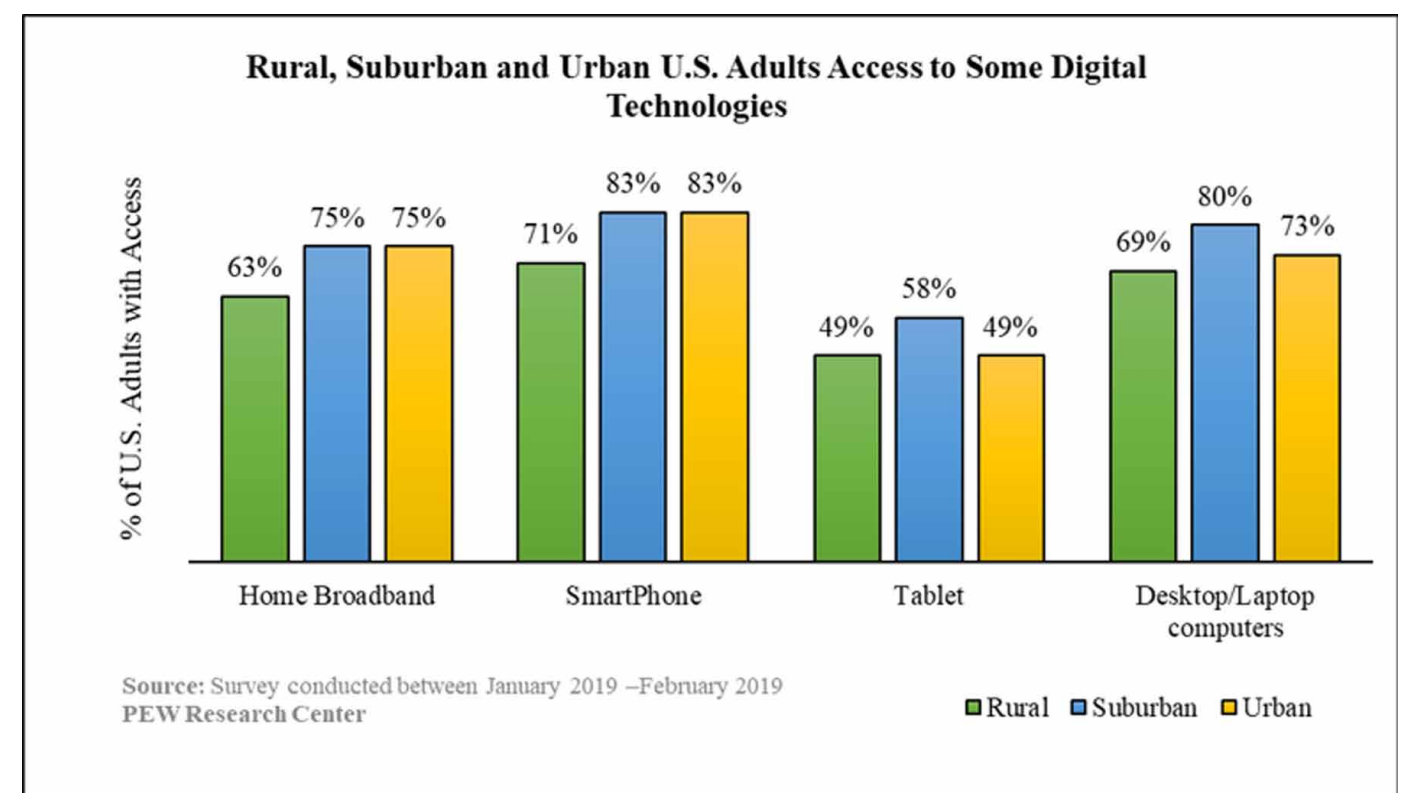

There is less research on adoption and use of information systems in non-market environment and public sector in general and in the context of state government agencies in US in particular (Liu et al, 2018). The knowledge applied by state government agencies has been mainly created outside the public sector. Liu et al (2018) argue that the information systems that may be perfectly adequate for use in a business with a limited set of strategic goals in private sector, may not work in a state government context where there are many independent agencies and a diverse set of stakeholders (Harvey et al., 2010). Besides, the ability to take risks is often limited in the public sector because of constitutional and legal constraints (Berman and West, 1998).

It is also important to note majority of the previous studies on e-government adoption have focused on citizens (e.g. Al-Shafi et al., 2009; Carter and Schaupp, 2008; McLeod et al., 2009; Chan et al., 2010; Schaupp et al., 2010; Jasimuddin et al., 2017) rather than employees of the public sector (Gupta et al., 2008; Dasgupta and Gupta, 2011). To fill this gap, the current study aims to identify the factors that impact attitude of 'early adopters' towards adoption of IT/IS and the focus is on public sector employees rather than citizens.

On the other hand, there are three categories of 'digital skills' requirements in IS literature (ECORYS 2016; Gekara et al., 2019). Basic computer literacy for everyday life (category 1), digital skills for the general workforce, enabling the effective use of IT/IS across all sectors (category 2), and digital skills for professional IT workforce (category 3). Gekara et al (2019) in their recent study argue there is plenty of research on category 1 (Bynner et al. 2010; Innovation and Business Skills Australia 2013) and category 2 (Deloitte Access Economics 2016). However, there is little research on category 3 digital skills requirements. There is a significant shortage in the digital skills required to effectively function in highly digitized work (Deloitte Access Economics 2016; Hajkowicz et al. 2016; Winthrop and McGivney 2016).

Change in technology causes staff to constantly complain about the tools needed to complete their tasks. We investigate the factors causing such backlash on information systems that are currently being implemented in public sector. We aim to develop and empirically test a model that can be used to explain adoption of IT/IS by public sector employees. We focus on the adoption of Office 365 in Illinois Department of Transportation since Office 365 was recently implemented in all the 
agencies across the State of Illinois. The main research question of the current study is: What are the key factors affecting attitude of public sector employees towards IT/IS and their adoption intention?

Government agencies struggle with information sharing and communication among internal and external stakeholders. Citizens' expectations are changing due to rapid technological advances, like the internet of things, artificial intelligence, and machine learning. Microsoft Office 365 has become the cloud-based productivity suit of choice, and SAP ERP a key system of record and business processes. The adoption of IT/IS promises great benefits to government agencies such as improved data quality, increased user productivity, and empowered teams ${ }^{1}$. Previous research in private sector and market environment has found ERP system implementation has a significant impact on organizational capabilities (Hwang and Min, 2015; Masini and Van Wassenhove, 2009, HassabElnaby, Hwang, and Vonderembse, 2012). Liu et al (2018) is one of few studies that has examined the validity of this relationship in public sector.

Moreover, previous research has mainly investigated demographic related indicators and adoption of IT/IS in voluntary context and there is little research on this topic in workplace and mandatory adoption context (Lameijer et al., 2017). To fill this gap, the focus of the current study is on workplace and mandatory adoption context. The findings provide insightful design and policy implications for IT/IS adoption by employees which is an essential first step for successful implementation of e-government, and delivery of government services to citizens.

Finally, most of the existing research on workforce, digital skills and digital transformation has taken an employer perspective (e.g. Lowry, Molloy and McGlennon 2008; Hajkowicz et al., 2016; Gekara et al., 2019). Our study adopts an employee-focused approach which can enhance our understanding of the digital skills needs of the government agencies or the economy as recently suggested by Gekara et al (2019).

Section 2 presents a brief summary of literature followed by the proposed research model and hypotheses. Section 3 explains research method including data collection and analysis followed by discussion of findings and concluding remarks in Section 4.

\section{LITERATURE REVIEW AND HYPOTHESES DEVELOPMENT}

The government's aim for digital transformation is mainly due to the ability to rapidly deploy new systems and business processes that allows them to act and react with great agility (Delloite, 2017; Janowski, 2015). A prime example of e-government is the information sharing among different agencies. The agencies that compose the government are now capable of crossing communication boundaries that once existed. The information on a citizen's background can be used in one agency but also transmitted to another one if necessary. The agencies are now working together to achieve the common goal of serving the public in a much more efficient and effective manner (Dawes, 2008; Janowski, 2015).

To continue serving the citizens in the most efficient way, the government needs to keep-up with technology innovations. In theory, the public sector employees do not have an option but to accept the new measures imposed by upper management and the executive level at their respective organizations. The decision-making and business structure of the public sector is functional. However, there is resistance by employees when it comes to adoption of new technology to perform their tasks.

Deloitte conducted a survey to analyze data within state agencies on why government employees are reluctant to accept new information technology. They found "76 percent of survey respondents believe digital technologies are disrupting the public sector and a whopping 96 percent also believe that this digital disruption is occurring within their respective domain areas" (Delloite, 2017). The potential early adopters are displaying resistance towards digital transformation because it is impacting them personally in their work environment. The problem is that government employees are used to performing their job a certain way and introducing a new IT/IS or a new process requires them to learn a new IT/IS and struggle while doing so. 
Previous studies have found older workers face particular difficulties adopting IT/IS resulting in 'lagged' adoption patterns among aging populations (Lameijer et al., 2017). However, explaining mechanisms has received little attention (Tams et al., 2014). Lameijer et al (2017) argue while the role of age during voluntary IT/IS adoption has been extensively studied (Czaja et al., 2006; Lam and Lee, 2006; Niehaves and Plattfaut, 2014; van Dijk and Hacker 2003), we need to investigate the mechanisms explaining demographics related variations in IT/IS adoption patterns (Tams et al., 2014), specifically in the work context where adoption often is mandatory. Rogers (2002) explains the impact of 'demographic' and 'psychological' characteristics on technology adoption followed by discussing the various stages of the adoption lifecycle which begins with the innovator, then the early adopter followed by early and late majority. The adoption lifecycle terminates the last stage with the laggards. The laggards adopt and accept the technology once their peers have adopted it.

Many technologies experience consumers' resistance (Claudy et al., 2010; Peattie 2010). Technology resistance analysis provides depth of understanding into the relatively under-researched area of the drivers and levels of innovation resistance. Innovation adoption studies promote proinnovation bias and neglect the technology resistance construct (Bagozzi and Lee, 1999; Kleijenen et al., 2009; Sheth, 1981; Szmigin and Foxall, 1998). Innovation resistance is conceptually different from innovation adoption (Bagozzi and Lee 1999; Kleijnen et al., 2009; Sheth 1981) and different from not-trying an innovation, which as Rogers (2002) points out can be overcome by giving potential users an opportunity to try the innovation; and could be the result of user's negative reaction or rational choice to new technology (Chen, Feng, Liu, \& Tian, 2019; Szmigin \& Foxall, 1998).

Economically, resistance implies delayed or no return on business and government investments. Socially, it implies wastage of resources. It is crucial, therefore, to understand the nature and drivers of technology resistance. Broadly, two forms of resistance can be identified: passive and active (Bagozzi and Lee, 1999; Kleijnen et al., 2009; Szmigin and Foxall, 1998). Passive resistance is generally related to lack of awareness and the active form of resistance refers to potential users who are aware of technology, and cognitively involved in evaluating the characteristics of the innovations but make a rational choice not to adopt. Active resistance can be manifested in three ways: postponement, rejection and opposition (Kleijnen et al., 2009; Szmigin and Foxall, 1998). Technical, business and management factors are the significant determinants decision making on IT adoption in public sector (Wu, Ding, Xu, Mo, \& Jin, 2016). Further, the economic and educational imbalances along with some geographical aspects are also consider the drivers for digital divide (Cruz-Jesus, Oliveira, \& Bacao, 2018). It has been observed that information quality mediates the effect of three organizational factors (management support, training, and user involvement) on IT/IS adoption (Rouibah, Dihani, \& Al-Qirim, 2020).

\subsection{Research Model}

A widely used model in technology adoption research is Technology Acceptance Model (TAM) (Davis, 1989). However, there are many other models in the same domain (Abduljalil \& Zainuddin, 2015). These models include Adoption Diffusion Theory (ADT) (Rogers, 2010), Theory of Reasoned Action (TRA) (Fishben and Ajzen, 1975), Theory of Planned Behavior (TPB) (Ajzen, 1991), Motivational Model (MM) (Davis et al.1992), Unified Theory of Acceptance and Use of Technology (UTAUT) (Venkatesh et al., 2003), Van Dijk Theory (van Dijk, 2005), and Spatially Aware Technology Utilization Model (SATUM) (Pick and Sarkar, 2016). This section reviews these theories (Table 1).

TAM was used for studying adoption of an innovation and spreading its use among a group of people. It is one of the most widely used theories in information system research to understand and predict whether users would adopt IT/IS (Lin, 2003; Mortenson and Vidgen, 2016; Wahid, 2007). Theory of Planned Behavior which is an extension of the Theory of Reasoned Action (TRA) explains the mandatory situation for performing a behavior. This extension involves the addition of one construct which is Perceived Behavioral Control (PBC) referring to "the perceived ease or difficulty of performing the behavior" (Ajzen, 1991). Therefore, TPB suggests that an individual's intention 
to perform a certain behavior is based on three constructs: attitude, subjective norms, and perceived behavioral control.

TPB model has been applied in several previous studies to predict individual's behaviors in multiple and diverse work settings (Hansen et al., 2004; Lu et al., 2009; Montano and Kasprzyk, 2015; Ozkan and Kanat, 2011; Pavlou and Chai, 2002; Pavlou and Fygenson, 2006; Shih and Fang, 2004). TPB has a good extendibility and explanatory power. The model structure is neither too simple nor too complex (explanatory power), and it has flexible extension mechanisms to incorporate more constructs according to researchers' needs (extendibility power) (Benbasat and Barki, 2007).

TPB is selected in view of its benefits over other theories. Adoption-Diffusion Theory (ADT) examines and describes the dynamics of digital divide from diverse adoption and diffusion attributes (Straub, 2009). However, the model does not include the behavioral and social factors, and it concentrates on IT access only without IT use. Theory of Reasoned Action (TRA) predicts and describes individual's behaviors based on their attitude and behavioral intention only. It doesn't discuss the impact of the behavioral control which makes it unreliable to predict non-volitional behaviors (Ackermann and Palmer, 2014).

While Van Dijk's theory helps to gain deep understanding of various perspectives related to IT/ IS adoption and digital divide and to trace their causes; it incorporates many factors and interrelated steps that make it too complex. Also, the model requires considerable efforts for data collection from multiple sources to prove the validity of the findings (Dijk, 2005). Similarly, Unified Theory of Acceptance and Use of Technology (UTAUT) was not selected for this study due to its complexity. Finally, Spatially Aware Technology Utilization Model (SATUM) is useful for examining digital divide on a large scale and population but it does not include individual level factors that affect IT access and use (Pick and Sarkar, 2016). The reviewed literature indicates that the models for studying IT/IS and e-government adoption by previous studies are normally based on one of the theories mentioned above. However, authors usually extend these theories and incorporate additional constructs in order to improve explanatory power of these models for different contexts.

Through observation and exploratory interviews with staff at Finance Department, the authors identified the following parameters as important factors for the adoption of Office 365 by employees: attitude, social pressure, management support, available resources, and IT support. Based on the above discussion and in order to achieve the objective of this paper and empirically verifying the hypotheses, we propose a model based on the theory of planned behavior and technology acceptance model, that is extended to include age, job responsibility, digital skills and trust in technology which can be applied for the context of public sector (Figure 2). As shown in Figure 2, Individuals' behaviors are directly influenced by their behavioral intention (BI); and indirectly influenced by attitude, subjective norms (SNs), and perceived behavioral control (PBC). Also, the proposed model shows existence of high-level constructs which affect the next level ones: behavioral beliefs affect attitudes, normative beliefs affect SNs, and control beliefs affect the PBC. According to the TAM model, behavioral beliefs is about having positive or negative attitude towards the behavior; normative beliefs is about the social pressure towards the behavior, and control beliefs define if performing the behavior is easy or difficult (Ajzen, 1991).

\subsection{Hypotheses Development}

TPB Constructs: Attitude measures individual's opinion towards performing a particular behavior which is IT/IS adoption in this study. Subjective norms $(S N)$ are used to measure the impact of social pressure on doing or not doing the behavior. Perceived behavioral control $(P B C)$ measures the extent to which performing a determined behavior is difficult or not. It is used to investigate the resources, knowledge, and ability needed to ease behavior. So, we put forward the following hypotheses:

Hypothesis 1 (H1): Positive attitude towards using IT/IS positively influence the intention to adopt IT/IS. 
Table 1. A Summary of Information Technology Adoption Theories

\begin{tabular}{|c|c|c|c|}
\hline Theory & Purpose & Constructs & Adopted By Other Studies \\
\hline $\begin{array}{l}\text { Theory of } \\
\text { Reasoned } \\
\text { Action } \\
\text { (TRA) }\end{array}$ & $\begin{array}{l}\text { To describe the relationship between } \\
\text { attitude and behavior (Gillmore, et } \\
\text { al., 2002) }\end{array}$ & $\begin{array}{l}\text { Attitude and subjective norm } \\
\text { (Ajzen and Madden, 1986) }\end{array}$ & $\begin{array}{l}\text { Hansen et 1., 2004; } \\
\text { Montano and Kasprzyk, } 2015\end{array}$ \\
\hline $\begin{array}{l}\text { Technology } \\
\text { Acceptance } \\
\text { Model } \\
\text { (TAM) }\end{array}$ & $\begin{array}{l}\text { To understand and predict users' } \\
\text { acceptance towards new technology } \\
\text { and information systems (Davis, } \\
\text { 1989) }\end{array}$ & $\begin{array}{l}\text { Perceived usefulness (PU) and } \\
\text { perceived ease of use (PEOU) } \\
\text { (Davis, 1989) }\end{array}$ & $\begin{array}{l}\text { Lin, 2003; } \\
\text { Mortenson and Vidgen 2016; } \\
\text { Wahid, } 2007\end{array}$ \\
\hline $\begin{array}{l}\text { Theory of } \\
\text { Planned } \\
\text { Behavior } \\
\text { (TPB) }\end{array}$ & $\begin{array}{l}\text { An extended version of the TRA } \\
\text { model that includes the mandatory } \\
\text { situation for performing a behavior } \\
\text { (Perceived Behavioral Control) } \\
\text { (Ajzen, 1991) }\end{array}$ & $\begin{array}{l}\text { Attitude, subjective norm and } \\
\text { perceived behavioral control } \\
\text { (Ajzen, 1991) }\end{array}$ & $\begin{array}{l}\text { Hansen et al. 2004; Lu et al. } \\
\text { 2009; Montano and Kasprzyk } \\
\text { 2015; Ozkan and Kanat 2011; } \\
\text { Pavlou and Chai 2002; Pavlou } \\
\text { and Fygenson 2006; Shih and } \\
\text { Fang } 2004\end{array}$ \\
\hline $\begin{array}{l}\text { Adoption- } \\
\text { Diffusion } \\
\text { Theory } \\
\text { (ADT) }\end{array}$ & $\begin{array}{l}\text { To explain how innovations are } \\
\text { adopted and spread among a group of } \\
\text { people (Pick \& Sarkar, 2016) }\end{array}$ & $\begin{array}{l}\text { Relative advantage, } \\
\text { compatibility, complexity, } \\
\text { trialability and observability } \\
\text { (Straub, 2009) }\end{array}$ & $\begin{array}{l}\text { Akiyoshi and Ono, 2008; } \\
\text { Allaway et al., 2003; } \\
\text { Lopez-Nicolas et al., 2008; } \\
\text { Pick and Sarkar, } 2016\end{array}$ \\
\hline $\begin{array}{l}\text { Model of PC } \\
\text { Utilization } \\
\text { (MPCU) }\end{array}$ & $\begin{array}{l}\text { To understand and predict } \\
\text { individual's personal computing } \\
\text { utilization behavior (Thompson, } \\
\text { Higgins, \& Howell, 1991) }\end{array}$ & $\begin{array}{l}\text { Job-fit, complexity, long- } \\
\text { term consequences, affect } \\
\text { towards use, social factors } \\
\text { and facilitating conditions } \\
\text { (Thompson, Higgins, \& } \\
\text { Howell, 1991) }\end{array}$ & $\begin{array}{l}\text { Frambach and Schillewaert, } \\
2002\end{array}$ \\
\hline $\begin{array}{l}\text { Motivational } \\
\text { Model (MM) }\end{array}$ & $\begin{array}{l}\text { To explain behavior towards } \\
\text { technology adoption and use (Davis } \\
\text { et al., 1992) }\end{array}$ & $\begin{array}{l}\text { Extrinsic motivation and } \\
\text { intrinsic motivation (Davis et } \\
\text { al., 1992) }\end{array}$ & $\begin{array}{l}\text { Abduljalil and Zainuddin, } \\
2015\end{array}$ \\
\hline $\begin{array}{l}\text { Unified } \\
\text { Theory of } \\
\text { Acceptance } \\
\text { and Use of } \\
\text { Technology } \\
\text { (UTAUT) }\end{array}$ & $\begin{array}{l}\text { To understand and measure users' } \\
\text { intention towards new technology } \\
\text { (Venkatesh, Morris, Davis, \& Davis, } \\
\text { 2003) }\end{array}$ & $\begin{array}{l}\text { Performance expectancy, } \\
\text { effort expectancy, social } \\
\text { influence, facilitating } \\
\text { conditions, gender, age, } \\
\text { experience and voluntariness } \\
\text { of use (Venkatesh, Morris, } \\
\text { Davis, \& Davis, 2003) }\end{array}$ & $\begin{array}{l}\text { Kijsanayotin et al. 2009; } \\
\text { Niehaves and Plattfaut 2014; } \\
\text { Oshlyansky et al. } 2007\end{array}$ \\
\hline $\begin{array}{l}\text { Van Dijk's } \\
\text { Theory of } \\
\text { Digital } \\
\text { Technology } \\
\text { Access }\end{array}$ & $\begin{array}{l}\text { To explain in detail the factors } \\
\text { that affect Information and } \\
\text { Communication Technologies (ICT) } \\
\text { access (Pick \& Sarkar, 2016) }\end{array}$ & $\begin{array}{l}\text { Users' positional categories, } \\
\text { personal categories, amount } \\
\text { of resources, and resources } \\
\text { access (Dijk, 2005) }\end{array}$ & $\begin{array}{l}\text { Van Dijk and Hacker 2003; } \\
\text { Van Dijk 2005; Van Dijk et } \\
\text { al. 2008; } \\
\text { van Dijk and van Deursen } \\
2012\end{array}$ \\
\hline $\begin{array}{l}\text { Spatially } \\
\text { Aware } \\
\text { Technology } \\
\text { Utilization } \\
\text { Model } \\
\text { (SATUM) }\end{array}$ & $\begin{array}{l}\text { To analyze digital divide on a } \\
\text { broader scale (Pick \& Sarkar, 2016) }\end{array}$ & $\begin{array}{l}\text { Dependent variables such as } \\
\text { broadband adoption, internet } \\
\text { access, hardware ownership... } \\
\text { etc., and independent } \\
\text { variables such as education, } \\
\text { economy, innovation, market } \\
\text { structure...etc. (Pick \& } \\
\text { Sarkar, 2016) }\end{array}$ & $\begin{array}{l}\text { Agarwal et al. 2009; } \\
\text { Nishida et al. 2014; } \\
\text { Shih and Venkatesh } 2004\end{array}$ \\
\hline
\end{tabular}

Hypothesis 2 (H2): Subjective norms regarding the use of IT/IS have a positive impact on the intention to adopt IT/IS.

Hypothesis 3 (H3): Perceived behavioral control over using IT/IS positively influence the intention to adopt IT/IS. 


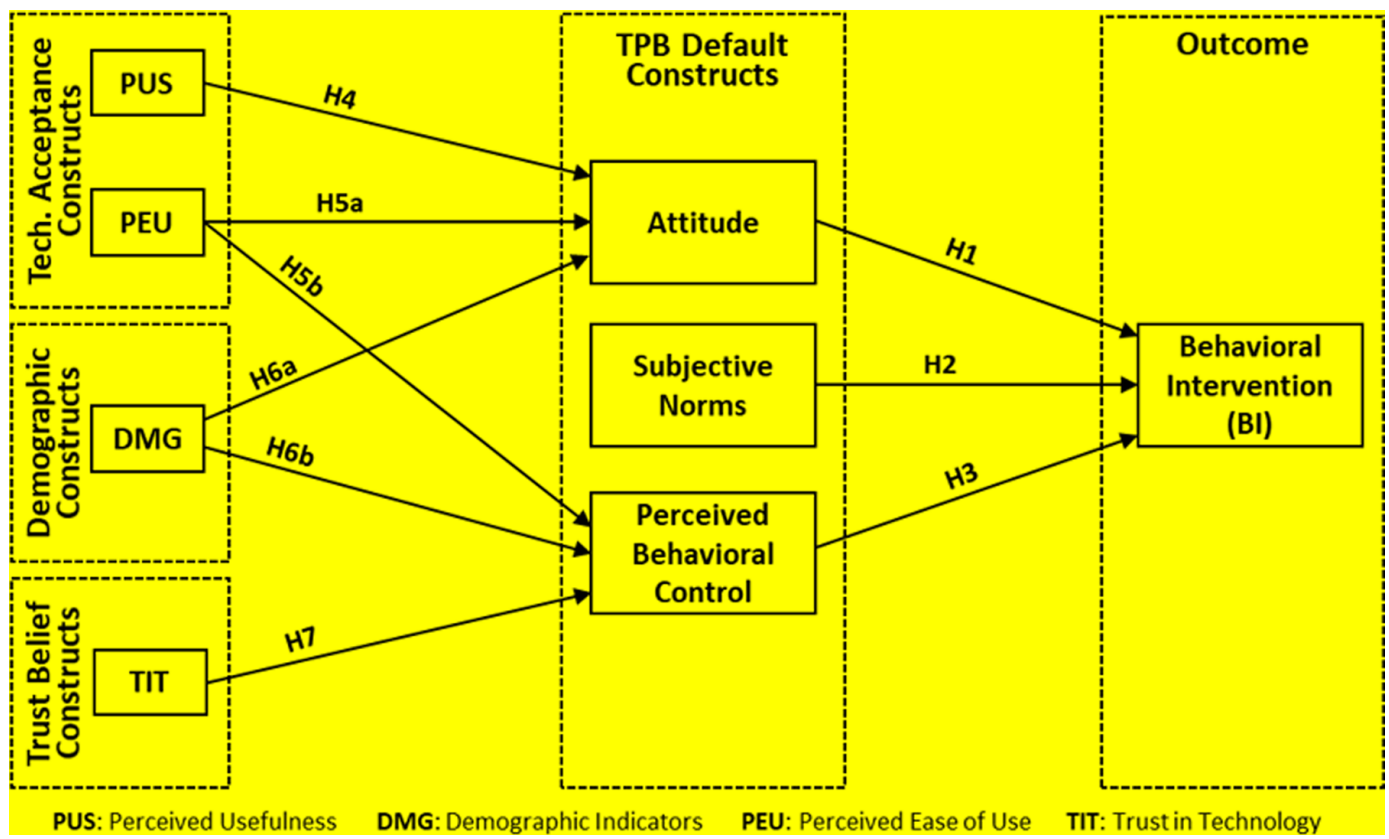

TAM Constructs: As technology keeps developing, new services, applications, systems, and products are being released. However, just because they are 'new' to the market, it does not mean potential users will accept them. The number of the people who accepts IT/IS depends on many factors such as age and income. When people are open to IT/IS and to learn about it, they are prone to accept new versions or new products in the market. IT/IS can be used for leisure or for work. Technology acceptance model suggests that technology's perceived usefulness and perceived ease of use are the key factors affecting intention to use IT/IS (Venkatesh et al., 2003).

IT/IS tend to be rated based on how useful they can be for personal or the office duties. If IT/ IS is rated as good or having a positive impact in workplace, more people will adopt it. Perceived usefulness (PUS) is defined as the degree to which a person believes that using a particular IT/IS would enhance their job performance (Davis, 1989). Hence, the following hypothesis is proposed:

Hypothesis 4 (H4): Perceived usefulness of IT/IS have a positive impact on the attitude toward adoption of IT/IS.

Another way of rating IT/IS is whether it is user-friendly. If IT/IS is easy to use, then it is considered good or advantageous. The employees would be more likely to utilize IT/IS if they find it easy to use which means no frustration is involved with the utilization of the IT/IS. Perceived Ease of Use (PEU) is the degree to which a person believes that using a particular IT/IS would be free of effort (Davis 1989). Hence, we propose the following hypotheses:

Hypothesis 5a (H5a): Perceived ease of use of IT/IS have a positive impact on the attitude toward adoption of IT/IS.

Hypothesis 5b (H5b): Perceived ease of use of IT/IS have a positive impact on the perceived behavioral control towards adoption of IT/IS. 
Demographic Constructs: This category of construct includes three indicators (age, digital skills and job responsibilities) that we found important based on literature and our observations in Illinois Department of Transportation.

Age is one of the important factors when it comes to adoption of IT/IS. Age has an inverse correlation with the perceived ease of use. For instance, the elderly users find it harder to interpret and recognize details when presented on the computer screen (Shirley, 2004). Analog medium like paper handouts are preferred over the digital copies like e-copies through computer screen. Elderly find it difficult to adopt IT/IS, because they find it hard to understand the complex processes. Recent studies have found that older people feel, "more often than the others that the work pace, things to be remembered, rules to be taken into consideration, difficulty of tasks, and monitoring of their work had increased" (European Commission, p. 98).

Digital skills are considered as the most evident and easily measurable factors impacting adoption of IT/IS among the public sector employees. Carter and Weerakkody (2008) found digital skills and access were parameters that had significant impact on digital divide.

IT/IS has driven the shift from the analog operations done with paper to digital medium using computers and internet. IT/IS has become an important aspect of the day to day operations in any office. Focused around the job responsibility of an individual in an organization to facilitate the daily operations are some of the facets that influence the need for IT/IS. Based on our observation in Illinois Department of Transportation, job responsibility would have a significant role to play in the adoption of IT/IS.

Hence, the following hypotheses are proposed:

Hypothesis 6a (H6a): Demographic indicators have a significant impact on the attitude toward adoption of IT/IS.

Hypothesis 6b (H6b): Demographic indicators have a significant impact on the perceived behavioral control towards adoption of IT/IS.

Trust Belief Construct: Many users particularly older workers do not trust the new IT/IS and prefer to continue using the one they are comfortable with. Trust in IT/IS asset plays a significant role in the willingness of the potential user to adopt and use the new IT/IS. This paper will investigate trust in technology as a parameter affecting the adoption of IT/IS among the state government employees. So, we propose:

Hypothesis 7 (H7): Trust in technology has a positive effect on the perceived behavioral control towards adoption of IT/IS.

\section{RESEARCH METHODS}

As mentioned earlier, our proposed model is based on the theory of planned behavior and technology acceptance model extended to include demographics and technology trust constructs (Figure 2) and the focus is on early adopters of Office 365 . Office 365 is a cloud-based Microsoft service that includes a number of products such as Word, Excel, PowerPoint, OneDrive and Outlook. Office 365 is a set of web-based tools that one can use to create, edit, manage and share documents, and communicate with any other member of the staff from any computer that has internet access, irrespective of operating system. It is provided by Microsoft and is the most commonly used business productivity suite globally. Office 365 offers some advanced features that enable employees to be more productive. First, Office 365 comes with more flexibility in which users can work on their cloud files anywhere using any device connected to the internet without installing the Office software on that device. Second, Office 365 comes with advanced data analysis and visualization features which can be found in Excel's 3D interactive map. Also, Office 365 contains a project management application, which is Office 365 Planner. $^{2}$ 


\subsection{Data Collection}

Our research is focused on public sector employees and the sample is from Finance Department at Illinois Department of Transportation (IDOT). IDOT is a state agency that is responsible for maintaining public roadways, while funding other modes of transportation including rail, air and public transit operations. The agency for the state is headquartered in Springfield, Illinois. However, throughout the state, IDOT has nine locations called districts.

For our study, the employees at IDOT headquarters in Springfield and Chicago were considered as a sample. IDOT has larger number of employees compared to other state agencies in Springfield. In a monthly memo in July 2017, they announced the decision for implementing Office 365 (IDOT, 2017). "Twenty agencies, boards, and commissions have now completed deployment of Office 365 for their employees -- bringing a fresh version of the Office suite and its collaboration and mobility features to their workplace and portable computers. Seven additional agencies are near completion and several large agencies are in the testing and deployment phase" (IDOT, 2017).

Early adopters in the IDOT went through the transformation of working with Office 2016, cloud-based office software from Microsoft, when the system migrated from offline based MS-Office 2010 to Cloud based MS-Office 2016. Based on our observations, many issues were hindering the adoption of IT/IS such as attitude, digital skills, and trust in the new technology. We used survey method to collect the data. The survey was created based on the proposed research model in which each variable is measured with two or more indicators. Table 2 illustrates the operationalization of the constructs. The sample comprises of 194 staff that have experienced the migration of the older version of Microsoft Office suite to the latest suite Office 365. The surveyed sample includes diverse groups of respondents illustrated in the data analysis, and discussions and findings section.

\subsection{Data Analysis}

Partial Least Squares (PLS) based on Structural Equation Modeling (SEM) was adopted to perform the data analysis. PLS-SEM is a comprehensive and broad approach for hypothesis testing among observed and latent variables (Hoyle, 1995). It is also applied for estimated applications or model validity and reliability testing (Bélanger and Carter, 2008). We used PLS-SEM to empirically test the proposed model, to determine the relationship among variables and to test the hypotheses we created. We used Smart PLS Version 3.2.7 that applies a two-step analysis approach. The first step was to test measurement model and the second step was to test the structural model. Moreover, we used a bootstrapping method to identify the significance level of loadings for reflective measures, weights for formative measures, and to test the path coefficient for correlations which is similar to hypothesis testing.

\subsubsection{Testing the Measurement Model}

The proposed model comprises of both formative and reflective measures. For evaluation of reflective measures (Table 3), we applied the convergent validity and the discriminant validity analysis. First, we examined the indicator reliability through factor loadings which analyses the associations among the observed variables using a small set of numeric factors (Thompson, 2007). Table 3 shows the loadings for reflective measures were acceptable for all variables except BI1, PBC2, and SNS3 as their loadings were below the minimum value which is 0.7 (Wong, 2013). For indicator reliability (i.e., loading 2), it is also required to be 0.7 or above (Wong, 2013; Hulland, 1999).

BI1, PBC2, PBC3, and SNS3 were below the required limit. Next, we assessed the internal consistency reliability using composite reliability (CR) which measures the consistency among indicators (Fornell and Larcker, 1981). Although the recommended benchmark for CR is 0.7 or more, 0.6 is accepted as a minimum value for exploratory research (Bagozzi and Yi, 1988). Therefore, BI and PBC indicators did not satisfy the acceptance criteria as their CR values were 0.27 and 0.39 respectively. Then, we estimated the average variance extracted (AVE) which shows the variance that 
Table 2. Operationalization of constructs

\begin{tabular}{|c|c|c|c|}
\hline Construct & Measure & Survey Question & Code \\
\hline \multirow{9}{*}{$\begin{array}{c}\text { TPB } \\
\text { Constructs } \\
\text { (Madden, } \\
\text { Ellen, \& } \\
\text { Ajzen, 1992) }\end{array}$} & Attitude & $\begin{array}{l}\text { - I think the new features of Office } 365 \text { are useful and } \\
\text { productive. }\end{array}$ & ATT1 \\
\hline & & - I think using Office 365 for daily tasks is a wise idea. & ATT2 \\
\hline & & - In my opinion, it is desirable to use Office 365. & ATT3 \\
\hline & $\begin{array}{l}\text { Subjective } \\
\text { Norms }\end{array}$ & $\begin{array}{l}\text { - People who are important to me think that I should use Office } \\
\qquad 365 .\end{array}$ & SNS1 \\
\hline & & - People who influence me think that I should use Office 365. & SNS2 \\
\hline & & $\begin{array}{l}\text { - Management has been supportive in letting me adapt to Office } \\
\qquad 365 .\end{array}$ & SNS3 \\
\hline & \multirow{3}{*}{$\begin{array}{c}\text { Perceived } \\
\text { Behavior } \\
\text { Control }\end{array}$} & $\begin{array}{l}\text { - I think Office } 365 \text { helps me complete my tasks more efficiently } \\
\text { and effectively. }\end{array}$ & PBC1 \\
\hline & & - I have a hard time in using Office 365. & $\mathrm{PBC} 2$ \\
\hline & & $\begin{array}{l}\text { - I think I have the resources, knowledge, and ability to use } \\
\text { Office } 365 \text {. }\end{array}$ & PBC3 \\
\hline \multirow{8}{*}{$\begin{array}{c}\text { TAM } \\
\text { Constructs } \\
\text { (Venkatesh and } \\
\text { Davis, 1996) }\end{array}$} & \multirow[t]{3}{*}{$\begin{array}{l}\text { Perceived } \\
\text { Usefulness }\end{array}$} & $\begin{array}{c}\text { - Using Office } 365 \text { enables me to accomplish my tasks more } \\
\text { effectively. }\end{array}$ & PUS1 \\
\hline & & - Using Office 365 makes it easier for me to carry out my tasks. & PUS2 \\
\hline & & $\begin{array}{l}\text { - I think using Office } 365 \text { increases my productivity and } \\
\text { improves my job performance. }\end{array}$ & PUS3 \\
\hline & \multirow{3}{*}{$\begin{array}{l}\text { Perceived Ease } \\
\text { of Use }\end{array}$} & - I think learning to use Office 365 is easy. & PEU1 \\
\hline & & - I think using Office 365 does not require a lot of mental effort. & PEU2 \\
\hline & & $\begin{array}{l}\text { - I think it is easy to use Office } 365 \text { to accomplish my daily } \\
\text { tasks. }\end{array}$ & PEU3 \\
\hline & $\begin{array}{l}\text { Behavioral } \\
\text { Intention }\end{array}$ & $\begin{array}{l}\text { - Assuming I had access to Office } 365 \text {, I intend to use Office } \\
\qquad 365 .\end{array}$ & BI1 \\
\hline & & $\begin{array}{l}\text { - Given that I had access to Office } 365 \text {, I predict that I would } \\
\text { use it. }\end{array}$ & $\mathrm{BI} 2$ \\
\hline \multirow{3}{*}{$\begin{array}{c}\text { Trust Belief } \\
\text { Constructs } \\
\text { (Mcknight, } \\
\text { Carter, } \\
\text { Thatcher, \& } \\
\text { Clay, 2011; } \\
\text { McKnight, } \\
\text { Cummings, } \\
\text { \& Chervany, } \\
\text { 1998) }\end{array}$} & $\begin{array}{l}\text { Trust in Office } \\
365\end{array}$ & - I trust Office 365 for my daily work tasks. & TRI1 \\
\hline & & - I can rely on Office 365 to complete my work. & TRI2 \\
\hline & & - I recommend the use of Office 365 in my workplace. & TRI3 \\
\hline $\begin{array}{l}\text { Demographic } \\
\text { Constructs }\end{array}$ & DMG & $\begin{array}{c}\text { - Age group } \\
\text { - Skill level } \\
\text { - Job responsibilities }\end{array}$ & $\begin{array}{l}\text { AGE } \\
\text { SKL } \\
\text { JBR }\end{array}$ \\
\hline
\end{tabular}

a construct can determine in relation to the variance resulted from measurement errors (Fornell and Larcker, 1981). Only BI measures fell below the threshold value which is 0.5 .

Next, we tested the discriminant validity using the square root of the AVE which validates a construct when its value is greater than the measure's correlations with the rest of the constructs. Table 4 shows the inter constructs correlations. To test the formative measures, we checked the measures' 
weight (Table 5) and found there were some insignificant measures with $t$-Statistics value less than 1.96 using significance level of 5\%. Then we checked the variant inflation factor (VIF) to measure the multi-collinearity or correlation among constructs in regression analysis. PUS2 VIF value was greater than the acceptable threshold which is equal to 5 (Hair et al., 2011).

\subsubsection{Testing the Structural Model}

Table 6 and Figure 3 present the results of testing the structural model. It was found that there is a positive relation between perceived usefulness and attitude $(\beta=0.46)$. Perceived ease of use is also positively related with attitude $(\beta=0.37)$. Therefore, hypotheses $\mathrm{H} 4$ and $\mathrm{H} 5 \mathrm{a}$ were supported. Moreover, there is a positive relation between perceived ease of use and perceived behavioral control

Table 3. Factor loadings of reflective measures and validity analysis

\begin{tabular}{|c|c|c|c|c|}
\hline & Loadings & Indicator Reliability & $\begin{array}{c}\text { Composite Reliability } \\
\text { (CR) }\end{array}$ & $\begin{array}{c}\text { Average Variance Extracted } \\
\text { (AVE) }\end{array}$ \\
\hline ATT1 & 0.894 & 0.80 & 0.958 & 0.884 \\
\hline ATT2 & 0.964 & 0.93 & & \\
\hline ATT3 & 0.96 & 0.92 & & \\
\hline BI1 & -0.304 & 0.09 & 0.27 & 0.474 \\
\hline BI2 & 0.924 & 0.85 & & \\
\hline PBC1 & 0.867 & 0.75 & 0.39 & 0.624 \\
\hline $\mathrm{PBC} 2$ & -0.757 & 0.57 & & \\
\hline PBC3 & 0.739 & 0.55 & & \\
\hline SNS1 & 0.922 & 0.85 & 0.822 & 0.625 \\
\hline SNS2 & 0.908 & 0.82 & & \\
\hline SNS3 & 0.449 & 0.20 & & \\
\hline TIT1 & 0.873 & 0.76 & 0.902 & 0.753 \\
\hline TIT2 & 0.868 & 0.75 & & \\
\hline TIT3 & 0.863 & 0.74 & & \\
\hline
\end{tabular}

Table 4. Inter-constructs correlations

\begin{tabular}{|c|c|c|c|c|c|c|c|c|}
\hline & ATT & BI & DMG & PBC & PEU & PUS & SNS & TIT \\
\hline ATT & 0.94 & & & & & & & \\
\hline BI & 0.15 & 0.688 & & & & & & \\
\hline DMG & -0.191 & 0.072 & NA & & & & & \\
\hline PBC & 0.765 & 0.163 & 0.255 & 0.79 & & & & \\
\hline PEU & 0.693 & 0.114 & 0.229 & 0.655 & NA & & & \\
\hline PUS & 0.719 & 0.151 & 0.126 & 0.708 & 0.685 & NA & & \\
\hline SNS & 0.566 & 0.103 & -0.12 & 0.358 & 0.365 & 0.522 & 0.791 & \\
\hline TIT & 0.711 & 0.106 & 0.247 & 0.778 & 0.589 & 0.603 & 0.417 & 0.868 \\
\hline
\end{tabular}


Table 5. Validity analysis for formative measures

\begin{tabular}{|c|c|c|c|}
\hline Item & Weight & T-Value & VIF \\
\hline AGE & -0.387 & 1.409 & 1.09 \\
\hline JBR & 0.552 & 2.255 & 1.102 \\
\hline SKL & 0.607 & 2.294 & 2.445 \\
\hline PEU1 & 0.431 & 4.389 & 2.528 \\
\hline PEU2 & 0.003 & 0.026 & 2.25 \\
\hline PEU3 & 0.652 & 7.073 & 3.468 \\
\hline PUS1 & 0.247 & 1.277 & 5.191 \\
\hline PUS2 & 0.633 & 3.009 & 4.005 \\
\hline PUS3 & 0.169 & 0.85 & \\
\hline
\end{tabular}

$(\beta=0.30)$, which also applies to the relationship between trust in technology and perceived behavioral control $(\beta=0.59)$. As shown in Figure 3, hypotheses H5b and $\mathrm{H} 7 \mathrm{in}$ the proposed model are supported. The results suggest there was a negative relation between attitude $(\beta=-0.23)$ and behavioral intention. Subjective norms $(\beta=0.06)$ and perceived behavioral control $(\beta=0.31)$ demonstrate a positive relation with adoption intention. Hypothesis $\mathrm{H} 3$ was found to be supported; however, $\mathrm{H} 1$ and $\mathrm{H} 2$ were not. Also, it was found demographics $(\beta=-0.04)$ was negatively related to attitude, and perceived behavioral control $(\beta=-0.05)$, and neither H6a nor H6b was supported.

\section{DISCUSSION, IMPLICATIONS AND CONCLUDING REMARKS}

The focus of the current study was a state agency in Illinois which has recently implemented Office 365 . The new digital process has replaced the conventional paper-based procedure for the invoices and has cut down operational costs of the department. The project took almost 13 months to implement and the system is not fully adopted by the employees yet. When the idea was first introduced, the resistance of the employees towards Office 365 was a concern. Managers were also concerned about the support available for post implementation phase, even during the pilot phase. Meanwhile, further concerns and questions were raised such as: How much effort is required for adjusting the system?

Table 6. Summary of testing the structural model

\begin{tabular}{|c|c|c|c|c|c|}
\hline Hypothesis & Description & Path Coefficient $(\boldsymbol{\beta})$ & Standard Error & T-Value & Results \\
\hline H1 & ATT $\rightarrow$ BI & -0.23 & 0.15 & 1.58 & Not Supported \\
\hline H2 & SNS $\rightarrow$ BI & 0.06 & 0.15 & 0.42 & Not Supported \\
\hline H3 & PBC $\rightarrow$ BI & 0.31 & 0.14 & 2.20 & Supported \\
\hline H4 & PUS $\rightarrow$ ATT & 0.46 & 0.08 & 6.09 & Supported \\
\hline H5a & PEU $\rightarrow$ ATT & 0.37 & 0.07 & 5.07 & Supported \\
\hline H5b & PEU $\rightarrow$ PBC & 0.30 & 0.06 & 5.13 & Supported \\
\hline H6a & DMG $\rightarrow$ ATT & -0.04 & 0.05 & 0.94 & Not Supported \\
\hline H6b & DMG $\rightarrow$ PBC & -0.05 & 0.04 & 0.99 & Not Supported \\
\hline H7 & TIT $\rightarrow$ PBC & 0.59 & 0.06 & 10.50 & Supported \\
\hline
\end{tabular}




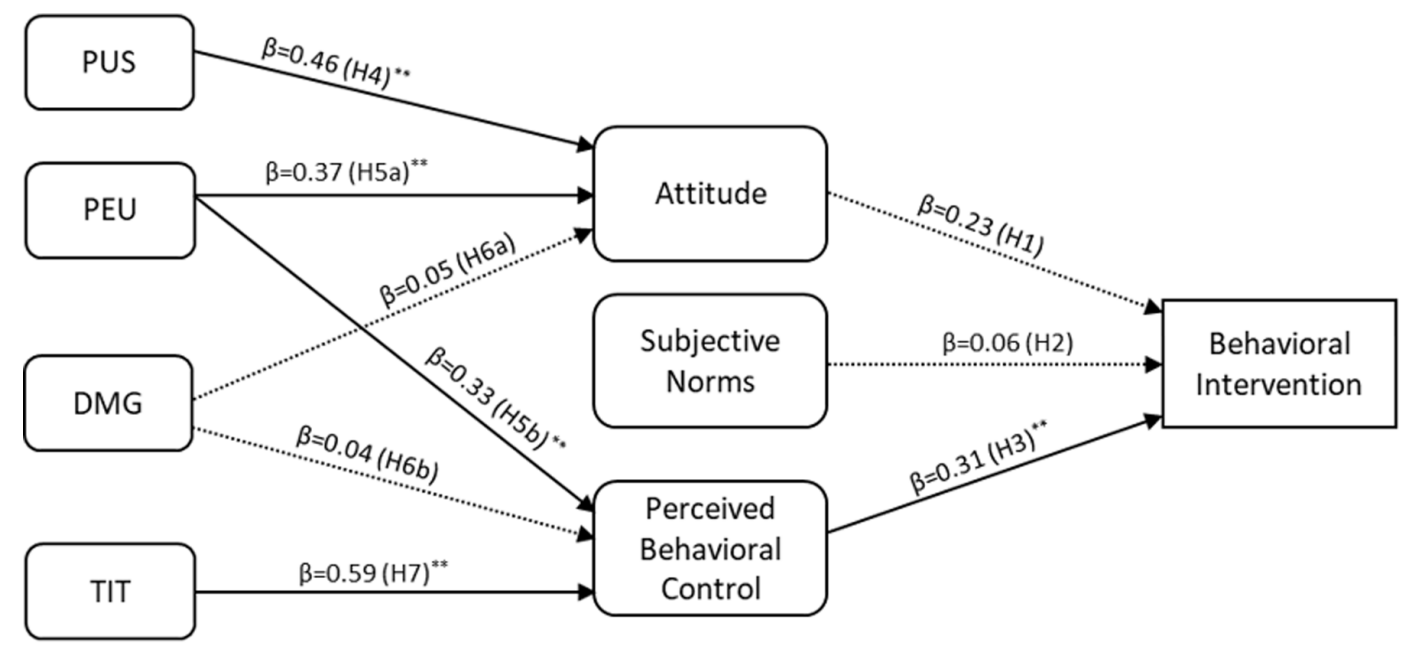

PUS: Perceived Usefulness

and Would it improve the efficiency if successfully implemented? Such question(s) were part of the journey of implementation of the new system.

We investigated the factors that impact the attitude and adoption behavior of IDOT employees towards IT/IS. The results suggest demographics and perceived behavioral control towards adopting IT/IS do not have significant impact on attitude. On the other hand, we found perceived ease of use, perceived usefulness and perceived behavioral control positively impact the attitude. Moreover, trust in technology has a positive effect on perceived behavioral control.

Since, only $8.5 \%$ of the employees are elderly people ( $>60$ years), age does not seem to be a significant factor on attitude; however, perceived ease of use and perceived usefulness are important factors. This shows that employees are finding Office 365 efficient and effective at workplace. The second indicator of demographics construct is job responsibility. The group of employees who categorize themselves with a job description as staff had the highest response rate in our survey. The next groups with the second highest response rate were the middle and lower management. The group with the lowest response rate was the group with people who identify themselves as top managers. These people tend to be very busy with meetings, projects, and administering staff. It seems employees trust in IT/IS overrides the impact of job responsibilities on perceived behavioral control. Job description is probably one of the demographic indicators that explain why people trust IT/IS. The results also suggest digital skills is not a significant indicator either. The demographic profile of the sample is summarized in Table 7.

The findings suggest the more useful IT/IS is (PUS), the more positive attitude early adopters have towards using it. Finally, the findings suggest flexible and easy to use (PEU) IT/IS needs less effort (PBC) to adopt. We also found early adopters' attitude (ATT) is dependent on perceived usefulness (PUS) and perceived ease of use (PEU) of IT/IS. Trust has a significant impact on perceived behavioral control and perceived behavioral control has a significant impact on adoption intention of IT/IS. However, the relationship between attitude and adoption intention was not significant. This can be explained as the decision to implement Office 365 was taken by top managers not the staff (mandatory versus voluntary adoption decision) (Chan et al., 2011). 
Table 7. Sample demographics

\begin{tabular}{|c|c|c|}
\hline Indicators & Frequency & Percentage \\
\hline Job Responsibility & & \\
\hline Executive level & 22 & $11.30 \%$ \\
\hline Top management & 7 & $3.60 \%$ \\
\hline Middle management & 33 & $17.00 \%$ \\
\hline Lower management & 33 & $17.00 \%$ \\
\hline Staff & 99 & $51.00 \%$ \\
\hline Age & & \\
\hline 20- 30 Years & & $10.50 \%$ \\
\hline $31-40$ Years & 21 & $30.50 \%$ \\
\hline $41-50$ Years & 61 & $20 \%$ \\
\hline $51-60$ Years & 40 & $27.50 \%$ \\
\hline$>60$ Years & 55 & $8.50 \%$ \\
\hline & 17 & \\
\hline Skills & & \\
\hline Well versed with IT Skills & 17 & $7.80 \%$ \\
\hline Well versed with Management Skills & 23 & \\
\hline Balanced Skillset & 153 & \\
\hline & & \\
\hline
\end{tabular}

\subsection{Research Implications}

Even though some scholars consider technology acceptance models to have reached its practical limit of explaining individual technology acceptance and use decisions (Venkatesh et al., 2003), IT adoption research has thrived (Venkatesh et al., 2012) mainly due to the diffusion of new IT/IS (Venkatesh et al., 2016). Previous research has extended existing technology acceptance models (such as TAM, TPB, UTAUT) as the baseline model with either new exogenous, endogenous, moderation, or outcome mechanisms. However, it is also argued IS discipline is at a crossroads regarding the possible theoretical contributions from further research into technology acceptance and use (Venkatesh et al., 2016).

According to Whetten (2009), one can make significant contributions of cross-context theorizing through either refining current context effects or identifying new context-effect theories. Consequently, Venkatesh et al (2016) identified eight dimensions of the context of technology acceptance and use from existing literature and aligned them at different levels in their framework. They specified the attributes of users, technology, tasks, research rationale, and events at the individual level and environment attributes, organization attributes, and location attributes at higher levels. Venkatesh et al. (2016) suggest future research can focus on adding libraries of new context effects from either of these dimensions (Whetten, 2009). Our paper contribute to technology acceptance literature by showing how it works differently in new context and by focusing on several dimensions of the context of technology acceptance and use: user class (public sector employees), technology class/IT artifact (Cloud-based Office 365); time class (pre-implementation/initial adoption), and organizational class (Finance Department of IDOT).

Our paper contributes to research in several areas. First, our paper contributes to research on IT/ IS adoption and digital transformation in the context of state government agencies and non-market 
environment. The advancement in IT/IS for government agencies provides a chance for IS researchers and practitioners to expand and share their knowledge with management and society (Gronlund and Horan, 2005). Second, majority of the previous studies on e-government adoption have focused on adoption of e-government by citizens (Chan et al., 2011; Jasimuddin et al., 2017) rather than employees of state government agencies. To fill this gap, our paper investigates the important factors that influence attitude of state government employees towards IT/IS and their intention to adopt. The focus is on state government employees rather than citizens and the factors include digital divide related factors such as digital skills divide. Third, majority of the existing research on digital skills has focused on basic computer literacy and digital skills for professional IT workforce (Gekara et al., 2019). Our paper contributes to research on digital skills requirements for general workforce which is less researched and understood.

Fourth, the Digital Service Act introduced in 2019 by Sen. Kamala Harris would invest $\$ 65$ million a year in federal, state and local digital teams to improve government systems that deliver services to consumers. The goal is to address US government's well-known shortcomings in technology including declining trust in e-government. ${ }^{3}$ We investigate the impact of trust as well as other factors on state government employees' adoption intention of IT/IS. Fifth, previous research has mainly investigated demographic related indicators and adoption of IT/IS in voluntary context and there is little research on this topic in workplace and mandatory adoption context (Lameijer et al., 2017). To fill this gap, the focus of the current study was on workplace and mandatory adoption context.

Finally, much of the existing research on workforce and digital skills has taken an employer perspective (e.g. Lowry, Molloy and McGlennon 2008; Hajkowicz et al., 2016; Gekara et al., 2019). Unlike previous research, our study adopts an employee-focused approach which can enhance our understanding of the digital skills needs of the government agencies and economy as recently suggested by Gekara et al (2019). "Information gathered from an employee-oriented study might also assist in addressing employer hesitation in introducing digital technologies in the workplace and/or employee resistance to technological change. Such research could also be used to identify those workers most at risk of being left behind in the digital transformation and where targeted training programs should to be developed' (Gekara et al., 2019).

\subsection{Practical Implications}

The findings also provide insightful design and practical implications for IT/IS deployment in public sector which is an essential first step for successful implementation of e-government and delivery of government services to citizens. The public sector employees in State of Illinois at Department of Transportation in Springfield and Chicago use the most popular office suite applications including MS Word (95\%), MS Excel (92\%) and MS Outlook (97\%). Based on the feedback collected by questionnaire, we found most of the respondents (public service employees) found it difficult to get accustomed to the newer version of the office suite, when managers decided to upgrade from office 2010 to office 2016.

One of the reasons for this was the design of the applications. For example, the locations of the menus had changed and most of the menus transitioned from being textual to graphical. The respondents highlighted Graphical User Interface (GUI) issues (38\%). The GUI issues impacted the efficiency of the respondents, as they found it difficult to navigate between the menus. While majority of the respondents used internet search to find answers for their questions related to the newly implemented suite, most of them preferred to consult the colleagues first, while IT helpdesk was mentioned as the last resort.

Lameijer et al (2017) argue "when IT design conflicts too much with cognitive capabilities and other demographic indicators, older adults may develop workarounds. Thy possess experience or skills unrelated to IT that enable them to build workarounds that actually are productive. Workaround have been found to not only impact IT negatively, but to sometimes play a supportive, facilitating role" (Haag et al., 2015; Li et al., 2017). 
A large number of respondents highlighted the need for training (46\%), and the lack of support from the IT staff at the Illinois Department of Transportation in the surveyed offices in Springfield and Chicago. Surprisingly, the respondents highlighted the need for making the trainings mandatory despite their busy work schedule. They also expressed concerns about the availability of the training manuals and post training. Since the respondents used search engines and videos to find answers for their questions, we recommend that it would be beneficial if the training manuals can be based on pictorial representations with comparisons made between the GUI placements of menus in old and new version(s) of the office suite.

The deployment of IT/IS in government agencies can be improved with the help of the findings of this paper. For example, when new technology is going to be released, top management need to make sure the time and the resources necessary to provide better training for early adopters are available since the feedback from the early adopters is important and necessary for adoption of technology by followers.

\subsection{Concluding Remarks}

This study investigated the factors impacting IT/IS adoption by employees in the context of state government agencies. The study focused on the Illinois Department of Transportation in Springfield and Chicago. A research model was proposed based on TPB and TAM which was extended by demographics and trust constructs. This study is not free from limitations. For example, we conducted this survey on staff at the Illinois Department of Transportation during implementation of Office 365. The findings may not be generalizable to other government institutions or agencies that maintain different organizational culture and environment. Future research should focus on the employees' satisfaction with adoption of IT/IS post implementation and investigate continuance intention. 


\section{REFERENCES}

Abduljalil, K. M., \& Zainuddin, Y. (2015). Integrating Technology Acceptance Model and Motivational Model Towards Intention to Adopt Accounting Information System, International Journal of Management. Accounting and Economics, 2(5), 346-359.

Agarwal, R., Animesh, A., \& Prasad, K. (2009). Research Note-Social Interactions and the "Digital Divide": Explaining Variations in Internet Use. Information Systems Research, 20(2), 277-294. doi:10.1287/isre.1080.0194

Ajzen, I. (1991). The Theory of Planned Behavior. Organizational Behavior and Human Decision Processes, 50(2), 179-211. doi:10.1016/0749-5978(91)90020-T

Akiyoshi, M., \& Ono, H. (2008). The Diffusion of Mobile Internet in Japan. The Information Society, 24(5), 292-303. doi:10.1080/01972240802356067

Al-Shafi, S., Weerakkody, V., \& Janssen, M. (2009). Investigating the adoption of eGovernment services in Qatar using the UTAUT model. In Proceedings of the 15th Americas Conference on Information Systems (pp. 1-10). Academic Press.

Allaway, A. W., Berkowitz, D., \& D’Souza, G. (2003). Spatial Diffusion of a New Loyalty Program through a Retail Market. Journal of Retailing, 79(3), 137-151. doi:10.1016/S0022-4359(03)00037-X

AtkinsonR. D.CastroD. (2008), Digital Quality of Life: Understanding the Personal and Social Benefits of the Information Technology Revolution. Available at https://ssrn.com/abstract=127818510.2139/ssrn.1278185

Bagozzi, R. P., \& Lee, K. (1990). Consumer resistance to and acceptance of innovations. Advances in Consumer Research. Association for Consumer Research (U. S.), 26(1), 218-225.

Baird, J. E., Zelin, R. C. II, \& Booker, Q. E. (2012). Is There a” Digital Divide” in the Provision of E-Government Services at the County Level in the United States? Journal of Legal. Ethical and Regulatory Issues, 15(1), 93-110.

Bannister, F., \& Connolly, R. (2012). Defining E-Governance. e-Service Journal: A Journal of Electronic Services in the Public and Private Sectors, 8(2), 3-25.

Basware. (2015). Whitepaper: Why are Governments Not Paperless. Retrieved from Basware: https://resource. basware.com/c/why-are-governments--not-paperless

Becker, S. A. (2003). Bridging Literacy, Language, and Cultural Divides to Promote Universal Usability of E-Government Websites. Journal of Electronic Commerce in Organizations, 53(1), i-iv.

Bélanger, F., \& Carter, L. (2009). The Impact of the Digital Divide on E-Government Use. Communications of the ACM, 52(4), 132-135. doi:10.1145/1498765.1498801

Bose, S., \& Rashel, M. (2007). Implementing E-Governance Using Oecd Model (Modified) and Gartner Model (Modified) Upon Agriculture of Bangladesh. In 10th international conference on Computer and Information Technology (ICCIT). IEEE.

Bynner, J., Reder, S., Parsons, S., \& Strawn, C. (2010). The three divides: the digital divide and its relation to basic skills and employment in Portland, USA and London, England. National Research and Development Centre for Adult Literacy and Numeracy.

Carter, L., \& Schaupp, L. C. (2008). Efficacy and acceptance in e-file adoption. In Proceedings of the 14th Americas Conference on Information Systems (pp. 1-11). Academic Press.

Carter, L., \& Weerakkody, V. (2008). E-Government Adoption: A Cultural Comparison. Information Systems Frontiers, 10(4), 473-482. doi:10.1007/s10796-008-9103-6

Caumont, A. (2013). Who's Not Online? 5 Factors Tied to the Digital Divide. PEW Research Center.

Chakravorti, B., \& Chaturvedi, R. (2017). Digital planet 2017: how competitiveness and trust in digital economies varies across the world. Fletcher School, Tufts University.

Chan, F., Thong, J. Y., Venkatesh, V., Brown, S., Hu, P., \& Tam, K. Y. (2011). Modeling Citizen Satisfaction with Mandatory Adoption of an E-Government Technology. Journal of the Association for Information Systems, 11(10), 519-549. doi:10.17705/1jais.00239 
Chen, Q., Feng, Y., Liu, L., \& Tian, X. (2019). Understanding consumers' reactance of online personalized advertising: A new scheme of rational choice from a perspective of negative effects. International Journal of Information Management, 44, 53-64. doi:10.1016/j.ijinfomgt.2018.09.001

Claudy, M. C., Garcia, R., \& O’Driscoll, A. (2015). Consumer resistance to innovation-A behavioral reasoning perspective. Journal of the Academy of Marketing Science, 43(4), 528-544. doi:10.1007/s11747-014-0399-0

Claudy, M. C., Michelsen, C., O’Driscoll, A., \& Mullen, M. R. (2010). Consumer Awareness in the Adoption of Microgeneration Technologies: An Empirical Investigation in the Republic of Ireland. Renewable \& Sustainable Energy Reviews, 14(7), 2154-2160. doi:10.1016/j.rser.2010.03.028

Cruz-Jesus, F., Oliveira, T., \& Bacao, F. (2018). The global digital divide: Evidence and drivers. Journal of Global Information Management, 26(2), 1-26. doi:10.4018/JGIM.2018040101

Czaja, S. J., Charness, N., Fisk, A. D., Hertzog, C., Nair, S. N., Rogers, W. A., \& Sharit, J. (2006). Factors Predicting the Use of Technology: Findings from the Center for Research and Education on Aging and Technology Enhancement. Psychology and Aging, 21(2), 333-352. doi:10.1037/0882-7974.21.2.333 PMID:16768579

Dasgupta, S., \& Gupta, B. (2011). Impact of organizational culture on technology use in a developing country. In Proceedings of the 17th Americas Conference on Information Systems (pp. 1-10). Detroit, MI: Academic Press.

Davis, F. D. (1989). Perceived Usefulness, Perceived Ease of Use, and User Acceptance of Information Technology. Management Information Systems Quarterly, 13(3), 319-340. doi:10.2307/249008

Davis, F. D., Bagozzi, R. P., \& Warshaw, P. R. (1992). Extrinsic and Intrinsic Motivation to Use Computers in the Workplace. Journal of Applied Social Psychology, 22(14), 1111-1132. doi:10.1111/j.1559-1816.1992.tb00945.x

Dawes, S. S. (2008). The Evolution and Continuing Challenges of E-Governance. Public Administration Review, 68(2), 86-102. doi:10.1111/j.1540-6210.2008.00981.x

Delloite. (2017). Digital Transformation: Bridging the New Digital Divide. Retrieved April 22, 2018, from https://www2.deloitte.com/content/dam/Deloitte/us/Documents/public-sector/us-fed-digital-transformationbridging-the-new-digital-divide.pdf

Deloitte Access Economics. (2016). Australia's digital pulse: developing the digital workforce to drive growth in the future. https://www.acs.org.au/content/dam/acs/acs-documents/PJ52569-Australias-Digital-Pulse-2016_ LAYOUT_Final_Web.pdf

ECORYS. (2016). Digital skills for the UK economy. https://www.gov.uk/government/uploads/system/uploads/ attachment_data/file/492889/DCMSDigitalSkillsReportJan2016.pdf

Ferro, E., Helbig, N. C., \& Gil-Garcia, J. R. (2011). The Role of IT Literacy in Defining Digital Divide Policy Needs. Government Information Quarterly, 28(1), 3-10. doi:10.1016/j.giq.2010.05.007

Finger, M., \& Pécoud, G. (2003), From E-Government to E-Governance? Towards a Model of E-Governance. Proceedings of the 3rd European Conference on E-Government-ECEG, 119-130.

Fishbein, M., \& Ajzen, I. (1975). Belief, Attitude, Intention and Behavior: An Introduction to Theory and Research. Philosophy \& Rhetoric, 10(2), 130-132.

Frambach, R. T., \& Schillewaert, N. (2002). Organizational Innovation Adoption: A Multi-Level Framework of Determinants and Opportunities for Future Research. Journal of Business Research, 55(2), 163-176. doi:10.1016/ S0148-2963(00)00152-1

Gekara, V., Snell, D., Molla, A., Karanasios, S., \& Thomas, A. (2019). Skilling the Australian workforce for the digital economy. NCVER.

Gore, A. (1997). Access America: Reengineering through Information Technology. DIANE Publishing.

Grönlund, ̊̊., \& Horan, T. A. (2005). Introducing E-Government: History, Definitions, and Issues. Communications of the Association for Information Systems, 15(1), 39-52.

Gupta, B., Dasgupta, S., \& Gupta, A. (2008). Adoption of ICT in a government organization in a developing country: An empirical study. The Journal of Strategic Information Systems, 17(3), 140-154. doi:10.1016/j. jsis.2007.12.004 
Hage, E. (2015). How Can Online Communication Enhance Older Adults' Social Connectivity? Implementation and Adoption Issues (Doctoral Dissertation). Groningen, The Netherlands: University of Groningen.

Hajkowicz, S., Reeson, A., Rudd, L., Bratanova, A., Hodgers, L., Mason, C., \& Boughen, N. (2016). Tomorrow's digitally enabled workforce: megatrends and scenarios for jobs and employment in Australia over the coming twenty years. CSIRO.

Hansen, T., Jensen, J. M., \& Solgaard, H. S. (2004). Predicting Online Grocery Buying Intention: A Comparison of the Theory of Reasoned Action and the Theory of Planned Behavior. International Journal of Information Management, 24(6), 539-550. doi:10.1016/j.jinfomgt.2004.08.004

Heeks, R. (2008). E-government for Development-Success and Failure in E-government Projects. Egovernment for Development Information Exchange, Coordinated by the University of Manchester's Institute for Development Policy and Management.

Helbig, N., Gil-García, J. R., \& Ferro, E. (2009). Understanding the Complexity of Electronic Government: Implications from the Digital Divide Literature. Government Information Quarterly, 26(1), 89-97. doi:10.1016/j. giq.2008.05.004

Janowski, T. (2015). Digital Government Evolution: From Transformation to Contextualization. Government Information Quarterly, 3(32), 221-236.

Jasimuddin, S. J., Mishra, N., \& Saif Almuraqab, N. A. (2017). Modelling the factors that influence the acceptance of digital technologies in e-government services in the UAE: A PLS-SEM Approach. Production Planning and Control, 28(16), 1307-1317. doi:10.1080/09537287.2017.1375144

Ke, W., \& Wei, K. K. (2004). Successful E-Government in Singapore. Communications of the ACM, 47(6), 95-99. doi:10.1145/990680.990687

Kijsanayotin, B., Pannarunothai, S., \& Speedie, S. M. (2009). Factors Influencing Health Information Technology Adoption in Thailand's Community Health Centers: Applying the Utaut Model. International Journal of Medical Informatics, 78(6), 404-416. doi:10.1016/j.ijmedinf.2008.12.005 PMID:19196548

Kleijnen, M., Lee, N., \& Wetzels, M. (2009). An Exploration of Consumer Resistance to Innovation and Its Antecedents. Journal of Economic Psychology, 30(3), 344-357. doi:10.1016/j.joep.2009.02.004

Koh, A. G. S. C. L., \& Maguire, S. (2005). E-organisation and its future implication for SMEs. Production Planning and Control, 16(6), 555-562. doi:10.1080/09537280500112439

Lam, J. C. Y., \& Lee, M. K. O. (2006). Digital Inclusiveness - Longitudinal Study of Internet Adoption by Older Adults. Journal of Management Information Systems, 22(4), 177-206. doi:10.2753/MIS0742-1222220407

Lameijer, C.S., Mueller, B., \& Hage, E. (2017). Towards Rethinking the Digital Divide - Recognizing Shades of Grey in Older Adults' Digital Inclusion. ICIS 2017 Proceedings, 11.

Li, Y., Haake, P., Mueller, B., \& Maedche, A. (2017). Explaining the Influence of Workarounds on the Effective Use of a Supply Chain Management System. European Conference on Information Systems (ECIS 2017).

Lin, C. A. (2003). An Interactive Communication Technology Adoption Model. Communication Theory, 13(4), 345-365. doi:10.1111/j.1468-2885.2003.tb00296.x

Liu, Y. J., Armstrong, D. J., \& Riemenschneider, C. (2018). The Relationship between Information Systems (IS) Assets, Organizational Capabilities, and IS-enabled Absorptive Capacity in U.S. State Information Technology Departments. Communications of the Association for Information Systems, 42, 6. doi:10.17705/1CAIS.04206

López-Nicolás, C., Molina-Castillo, F. J., \& Bouwman, H. (2008). An Assessment of Advanced Mobile Services Acceptance: Contributions from Tam and Diffusion Theory Models. Information \& Management, 45(6), 359-364. doi:10.1016/j.im.2008.05.001

Lowry, D., Molloy, S., \& McGlennon, S. (2008). Future skill needs: projections and employers' views. NCVER.

Lu, Y., Zhou, T., \& Wang, B. (2009). Exploring Chinese Users' Acceptance of Instant Messaging Using the Theory of Planned Behavior, the Technology Acceptance Model, and the Flow Theory. Computers in Human Behavior, 25(1), 29-39. doi:10.1016/j.chb.2008.06.002 
Madden, T. J., Ellen, P. S., \& Ajzen, I. (1992). A comparison of the theory of planned behavior and the theory of reasoned action. Personality and Social Psychology Bulletin, 18(1), 3-9. doi:10.1177/0146167292181001

Mcknight, D. H., Carter, M., Thatcher, J. B., \& Clay, P. F. (2011). Trust in a specific technology: An investigation of its components and measures. ACM Transactions on Management Information Systems, 2(2), 1-25. doi:10.1145/1985347.1985353

McKnight, D. H., Cummings, L. L., \& Chervany, N. L. (1998). Initial trust formation in new organizational relationships. Academy of Management Review, 23(3), 473-490. doi:10.5465/amr.1998.926622

McLeod, A., Pippin, S., \& Catania, V. (2009). Using technology acceptance theory to model individual differences in tax software use. In Proceedings of the 15th Americas Conference on Information Systems (pp. 1-11). Academic Press.

Montano, D.E., \& Kasprzyk, D. (2015). Theory of Reasoned Action, Theory of Planned Behavior, and the Integrated Behavioral Model. Health behavior: Theory, research and practice, 95-124.

Mortenson, M. J., \& Vidgen, R. (2016). A Computational Literature Review of the Technology Acceptance Model. International Journal of Information Management, 36(6), 1248-1259. doi:10.1016/j.ijinfomgt.2016.07.007

Mossberger, K., Wu, Y., \& Crawford, J. (2013). Connecting Citizens and Local Governments? Social Media and Interactivity in Major Us Cities. Government Information Quarterly, 30(4), 351-358. doi:10.1016/j. giq.2013.05.016

Nam, T. (2014). Determining the Type of E-Government Use. Government Information Quarterly, 31(2), 211-220. doi:10.1016/j.giq.2013.09.006

Niehaves, B., \& Plattfaut, R. (2014). Internet Adoption by the Elderly: Employing Is Technology Acceptance Theories for Understanding the Age-Related Digital Divide. European Journal of Information Systems, 23(6), 708-726. doi:10.1057/ejis.2013.19

Nishida, T., Pick, J. B., \& Sarkar, A. (2014). Japan' S Prefectural Digital Divide: A Multivariate and Spatial Analysis. Telecommunications Policy, 38(11), 992-1010. doi:10.1016/j.telpol.2014.05.004

Oshlyansky, L., Cairns, P., \& Thimbleby, H. (2007). Validating the Unified Theory of Acceptance and Use of Technology (Utaut) Tool Cross-Culturally. In Proceedings of the 21st British HCI Group Annual Conference on People and Computers. BCS Learning \& Development Ltd.

Ozkan, S., \& Kanat, I. E. (2011). E-Government Adoption Model Based on Theory of Planned Behavior: Empirical Validation. Government Information Quarterly, 28(4), 503-513. doi:10.1016/j.giq.2010.10.007

Pavlou, P. A., \& Chai, L. (2002). What Drives Electronic Commerce across Cultures? Across-Cultural Empirical Investigation of the Theory of Planned Behavior. Journal of Electronic Commerce Research, 3(4), 240-253.

Pavlou, P. A., \& Fygenson, M. (2006). Understanding and Predicting Electronic Commerce Adoption: An Extension of the Theory of Planned Behavior. Management Information Systems Quarterly, 30(1), $115-143$. doi: $10.2307 / 25148720$

Peattie, K. (2010). Green Consumption: Behavior and Norms. Annual Review of Environment and Resources, 359(2), 195-228. doi:10.1146/annurev-environ-032609-094328

Perrin, A. (2019). Digital gap between rural and nonrural America persists. Pew Research Center. Retrieved from https://www.pewresearch.org/fact-tank/2019/05/31/digital-gap-between-rural-and-nonrural-america-persists/

Pick, J., \& Sarkar, A. (2016). Theories of the Digital Divide: Critical Comparison. 49th Hawaii International Conference on System Sciences (HICSS), 3888-3897. doi:10.1109/HICSS.2016.484

Pick, J. B., \& Nishida, T. (2015). Digital Divides in the World and its Regions: A Spatial and Multivariate Analysis of Technological Utilization. Technological Forecasting and Social Change, 91(1), 1-17. doi:10.1016/j. techfore.2013.12.026

Pontiggia, A., \& Virili, F. (2010). Network Effects in Technology Acceptance: Laboratory Experimental Evidence. International Journal of Information Management, 30(1), 68-77. doi:10.1016/j.ijinfomgt.2009.07.001 
Rogers, E. (2002). Diffusion of Preventive Innovations. Addictive Behaviors, 27(1), 989-993. doi:10.1016/ S0306-4603(02)00300-3 PMID:12369480

Rouibah, K., Dihani, A., \& Al-Qirim, N. (2020). Critical Success Factors Affecting Information System Satisfaction in PublicSector Organizations: A Perspective on the Mediating Role of Information Quality. Journal of Global Information Management, 28(3), 77-98. doi:10.4018/JGIM.2020070105

Schaupp, L. C., Carter, L., \& McBride, M. E. (2010). E-file adoption: A study of US taxpayers' intentions. Computers in Human Behavior, 26(4), 636-644. doi:10.1016/j.chb.2009.12.017

Schou, C., \& Shoemaker, D. P. (2006). Information assurance for the enterprise: A roadmap to information security. McGraw-Hill, Inc.

Sheth, J. N. (1981). An Integrative Theory of Patronage Preference and Behavior. College of Commerce and Business Administration, Bureau of Economic and Business Research, University of Illinois.

Shih, C. F., \& Venkatesh, A. (2004). Beyond Adoption: Development and Application of a Use-Diffusion Model. Journal of Marketing, 68(1), 59-72. doi:10.1509/jmkg.68.1.59.24029

Shih, Y.-Y., \& Fang, K. (2004). The Use of a Decomposed Theory of Planned Behavior to Study Internet Banking in Taiwan. Internet Research, 14(3), 213-223. doi:10.1108/10662240410542643

Sung, W. (2016). A Study of the Digital Divide in the Current Phase of the Information Age: The Moderating Effect of Smartphones. Information Polity, 21(3), 291-306. doi:10.3233/IP-160398

Szmigin, I., \& Foxall, G. (1998). Three forms of innovation resistance: The case of retail payment methods. Technovation, 18(6-7), 459-468. doi:10.1016/S0166-4972(98)00030-3

Tams, S., Grover, V., \& Thatcher, J. (2014). Modern Information Technology in an Old Workforce: Toward a Strategic Research Agenda. The Journal of Strategic Information Systems, 23(4), 284-304. doi:10.1016/j. jsis.2014.10.001

UNPAN. (2010). Government Survey 2010 Leveraging E-Government at a Time of Financial and Economic Crisis. United Nations. Retrieved May 15, 2018, from http://unpan1.un.org/intradoc/groups/public/documents/ un-dpadm/unpan038851.pdf

Van Dijk, J., \& Hacker, K. (2003). The Digital Divide as a Complex and Dynamic Phenomenon. The Information Society, 19(4), 315-326. doi:10.1080/01972240309487

Van Dijk, J. A. (2005). The Deepening Divide: Inequality in the Information Society. Sage Publications.

Van Dijk, J. A., Peters, O., \& Ebbers, W. (2008). Explaining the Acceptance and Use of Government Internet Services: A Multivariate Analysis of 2006 Survey Data in the Netherlands. Government Information Quarterly, 25(3), 379-399. doi:10.1016/j.giq.2007.09.006

van Dijk, J. A., \& van Deursen, A. J. A. M. (2012), A Social Revolution Online? The Digital Divide Shifts to Gaps of Usage. 62nd Annual Conference of the International Communication Association, ICA 2012: Communication and Community.

Venkatesh, V., \& Davis, F. D. (1996). A model of the antecedents of perceived ease of use: Development and test. Decision Sciences, 27(3), 451-481. doi:10.1111/j.1540-5915.1996.tb01822.x

Venkatesh, V., Morris, M. G., Davis, G. B., \& Davis, F. D. (2003). User acceptance of information technology: Toward a unified view. Management Information Systems Quarterly, 27(3), 425-478. doi:10.2307/30036540

Venkatesh, V., Thong, J. Y. L., \& Xu, X. (2012). Consumer acceptance and use of information technology: Extending the unified theory of acceptance and use of technology. Management Information Systems Quarterly, 36(1), 157-178. doi:10.2307/41410412

Venkatesh, V., Thong, J. Y. L., \& Xu, X. (2016). Unified Theory of Acceptance and Use of Technology: A Synthesis and the Road Ahead. Journal of the Association for Information Systems, 17(5), 328-376. doi: $10.17705 / 1$ jais.00428 
Wahid, F. (2007). Using the Technology Adoption Model to Analyze Internet Adoption and Use among Men and Women in Indonesia. The Electronic Journal on Information Systems in Developing Countries, 32(1), 1-8. doi:10.1002/j.1681-4835.2007.tb00225.x

Whetten, D. A. (2009). An examination of the interface between context and theory applied to the study of Chinese organizations. Management and Organization Review, 5(1), 29-55. doi:10.1111/j.1740-8784.2008.00132.x

Winthrop, R., \& McGivney, E. (2016). Skills for a changing world. Brookings Institution. https://www.brookings. edu/wp-content/uploads/2016/05/Brookings_Skills-for-a-Changing-World_Advancing-Quality-Learning-forVibrant-Societies-3.pdf

Wu, J., Ding, F., Xu, M., Mo, Z., \& Jin, A. (2016). Investigating the determinants of decision-making on adoption of public cloud computing in e-government. Journal of Global Information Management, 24(3), 71-89. doi:10.4018/JGIM.2016070104

Yin, L., \& Jiahong, Z. (2014). The Influence of the Digital Divide to the Electronic Government Affairs. International Conference on Management of e-Commerce and e-Government (ICMeCG), 307-311. doi:10.1109/ ICMeCG.2014.69

\section{ENDNOTES}

1 https://microsoft.cioreview.com/cxoinsight/why-sap-erp-and-office-365-integration-will-help-yousucceed-in-today-s-digital-world-nid-23670-cid-50.html https://www.office.com/ https://eu.usatoday.com/story/opinion/2019/04/12/digital-government-respect-citizens-restore-trustdemocracy-column/3427525002/

Neetu Singh is an Assistant Professor of MIS at the University of Illinois Springfield. She has received her PhD in CIS from Georgia State University in 2016. Her dissertation was smart interventions for effective medication adherence. Her research interests are in health information technology, big data/advanced analytics adoption, and actionable business intelligence. She has presented papers in conferences including DESRIST, IEEE Wireless Telecommunications Symposium, AMCIS, HCl International and International CIS. She has published several refereed journal papers. 